\title{
A comparison of liveweight gain of two groups of weaners of different entry liveweight in an ad libitum fodder beet feeding system for finishing beef cattle
}

\author{
S.J. GIBBS ${ }^{1}$, B. SALDIAS ${ }^{1}$, J. WHITE ${ }^{2}$, D. WALSH ${ }^{2}$, N. STOCKER ${ }^{2}$, \\ C. TROTTER ${ }^{3}$, B. FISHER ${ }^{4}$, A. FISHER ${ }^{4}$, B. BANKS ${ }^{4}$ and S. HODGE ${ }^{1}$ \\ ${ }^{1}$ Lincoln University, PO Box 85084, Lincoln, New Zealand \\ ${ }^{2}$ Seed Force, PO Box 16625, Christchurch, New Zealand \\ ${ }^{3}$ Vetlife Centre for Dairy Excellence, 20 Wilson Street, Geraldine, New Zealand \\ ${ }^{4}$ Silverstream Charolais, 2105 Christchurch Akaroa Rd, RD2, New Zealand
}

Jim.Gibbs@fodderbeetclub.co.nz

\begin{abstract}
The use of fodder beet as the primary diet for finishing beef cattle is a recent New Zealand innovation. A system using ad libitum grazed fodder beet through autumn and winter to finish spring-born steers between 12 and 18 months old was developed. Fodder beet is a high energy yet comparatively low protein content feed, and the fodder beet system requires high liveweight gains on the crop and an early slaughter age for cost effective production. Lower liveweight weaners have a greater protein requirement for optimal weight gain, and the threshold entry liveweight for satisfactory performance in this feeding system was not yet established. The objective of this study was to quantify the effect of the entry liveweight of weaners on liveweight gain in the fodder beet feeding system. A group of 392 rising 1-year-old beef cattle fed using this system were divided at entry into three groups on unfasted liveweight (kg): A, 290-370; B, 240-260; and the remaining animals. The heaviest (group A: steer $\mathrm{n}=67,316 \pm 2.7 \mathrm{~kg}$; heifer $\mathrm{n}=45,312 \pm 2.5 \mathrm{~kg}$ ) and lightest (group B: steer $n=77,249 \pm 0.7 \mathrm{~kg}$; heifer $n=19$, $251 \pm 1.0 \mathrm{~kg}$ ) groups were then treated identically on $\mathrm{ad}$ libitum fodder beet to compare liveweight gain across 130 days on crop. The mean liveweight daily gain $(\mathrm{kg} /$ day) for group A was significantly greater than group $\mathrm{B}$, and greater for the steers compared to heifers in group A (0.98 and 0.85), but not in group B (0.82 and 0.81 ). Mean liveweight gain as a proportion of entry liveweight was greater in group B, and greater in steers. Both mean daily liveweight gain and mean liveweight gain as a proportion of entry liveweight were positively correlated with entry liveweight, but the $\mathrm{R}^{2}$ of both was low ( 0.14 and 0.05 , respectively). Mean daily liveweight gain values of this magnitude are greater than those previously reported for alternative winter crops, and satisfactory for finishing beef cattle in this system. This study suggests the use of beef cattle above $240 \mathrm{~kg}$ liveweight as weaners in this fodder beet feeding system, both steers and heifers, is satisfactory
\end{abstract}

for achieving acceptable slaughter liveweight before 18 months old.

Keywords: beef production, fodder beet, finishing cattle, ad libitum fodder beet intakes.

\section{Introduction}

In New Zealand, beef production is almost exclusively pasture based, with spring calving, and supplementary feeding is generally restricted due to the comparatively high cost of cereal grains in New Zealand (Clark \& Woodward 2007; Gibbs \& Hughes 2008; Gibbs \& Saldias 2014a). The majority of beef production systems are dryland, so seasonal pasture supply is the driver for liveweight gain. As a consequence, finishing prime cattle before the second winter is the exception, and most steers are slaughtered after 26 months of age (Morris 2013). This slaughter age is greater than competitor nations such as the USA and Europe (1216 months), where cereal grains are used due to the comparatively low costs and higher returns. Increased slaughter age typically reduces carcass quality and introduces greater variability of quality, both of which increase the difficulty of marketing New Zealand prime beef.

The recent development of a system of grazed fodder beet (Beta vulgaris) fed ad libitum as a primary diet in New Zealand beef steers has opened the potential to increase their liveweight gain in seasons of lower pasture supply, reducing the slaughter age to less than 18 months (Gibbs \& Saldias 2014a). Fodder beet is a high yielding crop, so the cost has been as low as 5-10 cents/kg DM in commercial operations in 2015 (Gibbs unpublished data), and typical stocking rates for the 100-150 days are $20-30$ cattle per hectare.

The system uses grazed fodder beet fed ad libitum to weaner calves with tightly restricted additional feed inputs, as pasture or conserved feed, to reduce the cost of production. By using high intakes in autumn and winter to maintain strong liveweight gains, cattle are of 
a suitable liveweight in spring to maximise use of the increased quality and quantity of pasture available then, and thereby achieve typical slaughter weights before grass quality declines in late summer.

Fodder beet is high in metabolisable energy (ME; $12 \mathrm{MJ} / \mathrm{kg} \mathrm{DM}$ ) and typical New Zealand crops have an adequate protein content for adult drystock (Gibbs \& Saldias 2014b), making it suitable for those months where pasture growth is either moderate or low, fitting with the seasonal beef finishing system of New Zealand (Korte et al. 1987). Recent research (Prendergast \& Gibbs 2015) has demonstrated that in yearling steers (>280 kg liveweight) growing at approximately $1 \mathrm{~kg} /$ day for 40 days, ad libitum fodder beet diets (mean DM intake $5.6 \mathrm{~kg}+1 \mathrm{~kg}$ grass silage) were associated with comparatively high rumen $\mathrm{pH}$, unusually low rumen ammonia concentrations, but high microbial protein production, compared with ryegrass diets. However, industry standard liveweight at entry to fodder beet systems are typically lower than those reported in this current study.

To finish spring-born calves before 18 months of age, strong liveweight gain must be maintained from weaning, and this requires a higher protein supply compared with adult stock. The protein content is liveweight dependant with increasing nitrogen requirements per unit of fermentable $\mathrm{ME}$ as liveweight decreases (Prendergast \& Gibbs 2015). There are no available studies delineating the lower liveweight threshold of weaners suitable for use in a forage system of high energy and restricted protein supply that has time-critical weight gain requirements for satisfactory profitability, or describing the scale of any differences in weight gain due to entry liveweight. There is also no published information on the effect on performance of using either steers or heifers in this system. Therefore, this study aimed to compare the liveweight gain in a system of ad libitum fodder beet grazing between two groups of weaner beef cattle (mixed steers and heifers), of different mean entry liveweights: one at the upper end of industry expectations, and one similar to an industry standard.

\section{Materials and methods}

Two groups of calves were selected on liveweight from a group of 392 weaners entering an ad libitum fodder beet feeding system. The trial was conducted at Silverstream Charolais Farm, Banks Peninsula, New Zealand. A fodder beet crop (cv. 'Brigadier', Seed Force, Christchurch) was used as a primary feed for 130 days (from the 5 May to the 12 September). The crop diet was supplemented by an irrigated ryegrass and white clover pasture until 10 June, and then a silage made from that pasture until 12 September.

All animals were fitted with an electronic identification (ear tags) and at the start of the trial were weighed after grazing a daily allocation of pasture for three hours. According to their initial liveweight, animals were allocated to one of the three groups: group A (290-370 kg; steer $\mathrm{n}=67$, mean $316 \pm 2.7 \mathrm{~kg}$; heifer $\mathrm{n}=45$, mean $312 \pm 2.5 \mathrm{~kg})$; and group $\mathrm{B}(240-260$ $\mathrm{kg}$; steer $\mathrm{n}=77,249 \pm 0.7 \mathrm{~kg}$; heifer $\mathrm{n}=19,251 \pm 1.0 \mathrm{~kg}$ ); and a further group of all the remaining animals outside of those weights that were not included in the trial.

Before the start and at the conclusion of the trial a DM yield assessment of the crop was carried out, at the transition face region and in the last remaining hectare, respectively. This was done by the method described by Gibbs (2011). Briefly, three random sites were chosen in which a $4 \mathrm{~m}$ row was measured in each. Plants were counted in each metre of row and the total wet weight was recorded (bulb and leaf separately). Two representative plants from each $4 \mathrm{~m}$ row were kept for dry matter (DM) assessment. Each bulb was cut in a half from the crown to the tip, and then into quarters. Two quarters were afterward cut into $2 \mathrm{~cm}$ cubes and weighed for duplicate DM calculations. The leaf was also cut in half (length wise) and duplicate samples for DM were also used. All samples were dried at $65^{\circ} \mathrm{C}$ to a constant weight, approximately 21 days. Grass allocation was done by the assessment of standing dry matter cover using pasture height, with pre-grazing covers of $3500-4000 \mathrm{~kg} \mathrm{DM} / \mathrm{ha}$ and postgrazing residuals maintained at $1100-1500 \mathrm{~kg} \mathrm{DM} /$ ha. All animals grazed the same pasture, with groups separated by a fence.

All stock in both groups were treated similarly throughout the trial. The animals were under direct veterinary supervision throughout the trial. The stock were transitioned onto fodder beet for a period of 21 days using best practice protocols for young stock (Gibbs \& Saldias 2014a). Briefly, the cattle were acclimated to the fodder beet for 21 days prior to starting grazing the crop, a period in which they were grazing ad libitum ryegrass and white clover pasture (post-grazing covers $>2000 \mathrm{~kg} \mathrm{DM} / \mathrm{ha}$ ). Fodder beet was harvested with the leaf intact and fed to the steers three times weekly at less than $0.5 \mathrm{~kg} \mathrm{DM} /$ day on the pasture, with the bulbs opened up.

The cattle were stocked at 20 per hectare of fodder beet. For the first day on the crop, on a group basis each animal was offered $0.5 \mathrm{~kg}$ DM of fodder beet with $4 \mathrm{~kg}$ DM of pasture, both by strip grazing behind a hotwire with daily allocations. Thereafter every second to third day the fodder beet allocation was increased by $0.5 \mathrm{~kg}$ DM per steer as the cattle in both groups consumed the allocation, and the access to the pasture was reduced slowly until day 18 where the diet was composed by a ratio of an estimated 3-3.5 $\mathrm{kg}$ DM fodder beet and $1 \mathrm{~kg} \mathrm{DM}$ of pasture, a ratio of $75-78 \%$ fodder beet. 
This ratio was kept for the next 7 days and afterwards fodder beet allocation was increased over 3 days until approximately $25 \%$ of the previous daily bulb allocation was still available 24 hours later. The residual bulb was eaten over the next 2 days, leaving no visible bulb after this, and this was considered ad libitum intake. This procedure was maintained throughout the trial period.

The steers were grazed on this system from the 5 May to the 10 June and then $1 \mathrm{~kg} \mathrm{DM} /$ day of grass silage was substituted for the pasture from the 11 June to the 12 September. From day 10 of the transition period, all the cattle were kept on the crop except for 2 hours daily where they grazed the grass allocation in autumn (from 5 May to 10 June). The daily intake of fodder beet increased with appetite across the trial to an estimated 8.5-9 kg DM, but the allocation of supplement (pasture or silage) remained at $1 \mathrm{~kg} \mathrm{DM}$ daily for the entire period of the trial, a ratio of $85-90 \%$ fodder beet at the conclusion.

Prior to entry to fodder beet grazing, each steer received two vaccinations against clostridial diseases ("Covexin", Intervet, New Zealand), a treatment for gastro-intestinal nematodes ("OxyFen", Ancare, New Zealand) and trace element supplementation by injection ("Multimin+Cu", Virbac, New Zealand). All stock illnesses and deaths were noted and post mortem assessments completed on carcasses to determine cause of death.

The animals in each group were grazed separately for the trial in adjacent paddocks. After 130 days grazing the crop, all animals were weighed 3 hours after morning allocation of fodder beet and removed from the crop. The entry and exit liveweights were used to calculate mean daily liveweight gain (LWT gain/day) and the proportion of entry liveweight represented by liveweight gain over the 130 days grazing (LWT gain $\%$ ) for both heifers and steers in both entry size groups. Because the replicates in each group were not balanced, the data were analysed by a general linear model using Minitab v16 software, with post hoc comparisons of the four treatment groups performed using a Tukey test. Overall relationships between LWT gain/day and LWT gain \% with the entry liveweight were assessed using linear correlation. Rainfall data for each month the animals were fed on crop was obtained from the local Lincoln NIWA station records.

\section{Results and Discussion}

There were highly significant differences $(<0.001)$ in the mean LWT gain/day and the mean LWT gain \% over the trial period between groups A and B, and significant difference $(<0.05)$ between steers and heifers in group $\mathrm{A}$, and in the group $\times$ gender interaction (Table 1 ). Liveweight gain/day ranged between $0.61-1.33 \mathrm{~kg}$ for steers and $0.55-1.21 \mathrm{~kg}$ for heifers in group A, and $0.52-1.23 \mathrm{~kg}$ for steers and $0.49-1.23 \mathrm{~kg}$ for heifers in group B. The mean LWT gain \%, however, ranged between $16.4-52.5 \%$ in steers and $21.7-48.6 \%$ in heifers in group A, and $26.2-65.3 \%$ in steers and $24.8-$ $63.5 \%$ in heifers in group B.

In terms of final liveweight, the initially heavier group A animals remained heavier than the group B animals, with the group A steers having the heaviest final weights (Table 1). The average final liveweight of the group B heifers and steers was almost identical at $355.3 \mathrm{~kg}$. The comparatively high values reported here for heifers in both groups, suggest there is potential for effective use of heifers in this system. Liveweight gain was significantly higher in group A than group $\mathrm{B}$ overall, although this was predominantly due to the group A steers mean LWT gain/day (Table 1, Figure 1). Conversely, mean LWT gain \% was lower in group A than in group B overall, as the increase in heifers in group A (35\%) was significantly lower than that of the steers or the group B heifers (Table 1, Figure 2).

Table 1 Final liveweights (LWT) and gains of beef cattle fed on an ad libitum fodder beet grazing system at Banks Peninsula, New Zealand, for 130 days (means \pm SEM). Means not sharing a letter code were designated as significantly different $(\mathrm{P}<0.05)$ using a Tukey test.

\begin{tabular}{|c|c|c|c|c|c|c|c|}
\hline & \multicolumn{2}{|c|}{ Group A } & \multicolumn{2}{|c|}{ Group B } & \multirow[b]{2}{*}{$\mathbf{P}_{\text {Group }}$} & \multirow[b]{2}{*}{$\mathbf{P}_{\text {Sex }}$} & \multirow[b]{2}{*}{$\mathbf{P}_{\text {Interaction }}$} \\
\hline & Steers & Heifers & Steers & Heifers & & & \\
\hline $\mathrm{N}$ & 65 & 45 & 77 & 19 & & & \\
\hline Final LWT (kg) & $\begin{array}{c}443.4^{\mathrm{a}} \\
(4.6)\end{array}$ & $\begin{array}{c}423.0^{\mathrm{b}} \\
(3.7)\end{array}$ & $\begin{array}{c}355.3^{c} \\
(2.4)\end{array}$ & $\begin{array}{c}355.3^{c} \\
(6.8)\end{array}$ & 0.000 & 0.026 & 0.026 \\
\hline LWT gain (kg/day) & $\begin{array}{l}0.98^{a} \\
(0.02)\end{array}$ & $\begin{array}{l}0.86^{b} \\
(0.02)\end{array}$ & $\begin{array}{l}0.82^{b} \\
(0.02)\end{array}$ & $\begin{array}{l}0.81^{b} \\
(0.05)\end{array}$ & 0.000 & 0.011 & 0.031 \\
\hline LWT gain (\% entry LWT) & $\begin{array}{l}40.5^{a} \\
(0.82)\end{array}$ & $\begin{array}{l}35.8^{b} \\
(0.89)\end{array}$ & $\begin{array}{l}42.5^{a} \\
(0.92)\end{array}$ & $\begin{array}{l}41.7^{a} \\
(2.53)\end{array}$ & 0.001 & 0.025 & 0.123 \\
\hline
\end{tabular}




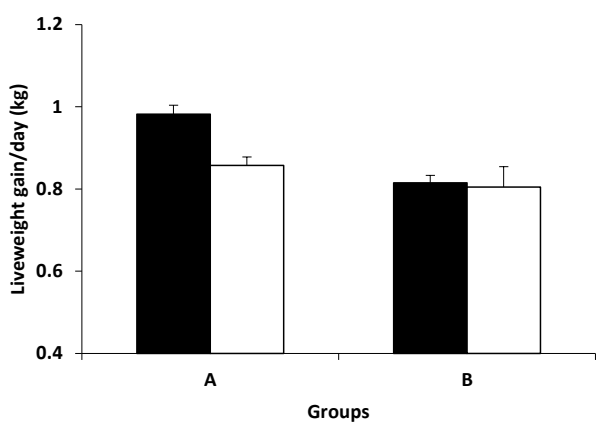

Figure 1 The liveweight gain ( $\mathrm{kg} /$ day) of steers and heifers fed ad libitum fodder beet with $1 \mathrm{~kg}$ dry matter of additional forage for 130 days (means \pm SEM). Group A were 290-370 kg liveweight, group B were 240-260 kg.

Previously reported mean daily liveweight gains of beef weaners or yearlings fed forages for periods of 60 days or more, including across winter, are substantially lower than the values reported here. Woods et al. (1995) reported values of $0.64 \mathrm{~kg} /$ day for weaner bulls on kale in autumn, and McPherson et al. (1989) 0.23-0.50 $\mathrm{kg}$ /day for yearling steers and heifers on ryegrass and clover pastures. Thompson \& Monteath (1974) reported gains of $0.30-0.58 \mathrm{~kg} /$ day for mobs greater than 20 steers fed grain with hay in feedlots in New Zealand, Joyce \& Brunswick (1977) reported 0.81-0.83 kg/ day over 179 days on lucerne in spring and summer, and Scales \&Taylor (1978) reported weaner steers on high planes of nutrition using pasture, hay and grains across winter achieved $0.67 \mathrm{~kg} /$ day. Journeaux et al. (1987) used system modelling to suggest yearling bulls required an autumn/winter LWT gain/day of between $0.48-0.83 \mathrm{~kg}$ to finish profitably at 16 months old and $220 \mathrm{~kg}$ carcass, considerably lower than the mean LWT gain/day achieved by group A steers in this study and similar to both group heifers and the steers of group B. Sheath \& McCall (1994) in a review suggested 0.5 $\mathrm{kg} /$ day across that winter period was "satisfactory" for efficient beef production.

As typical slaughter weight targets for steers are 500 $\mathrm{kg}$, and spring and early summer offer approximately 120 days of optimal weight gain, animals of $350 \mathrm{~kg}$ liveweight by spring are typically finished by 18 months old in summer in highly managed systems. Liveweight gains of above $0.8 \mathrm{~kg} /$ day across autumn and winter in animals with an entry weight of $240 \mathrm{~kg}$, as reported here, are therefore adequate for this approach. In addition, while DM yields and stocking rates are not always reported, there are no available reports of similarly high mean daily gains at similar stocking rates to those used in this trial. The higher liveweight gains observed suggest that the use of ad libitum fed fodder beet systems can deliver performance suitable

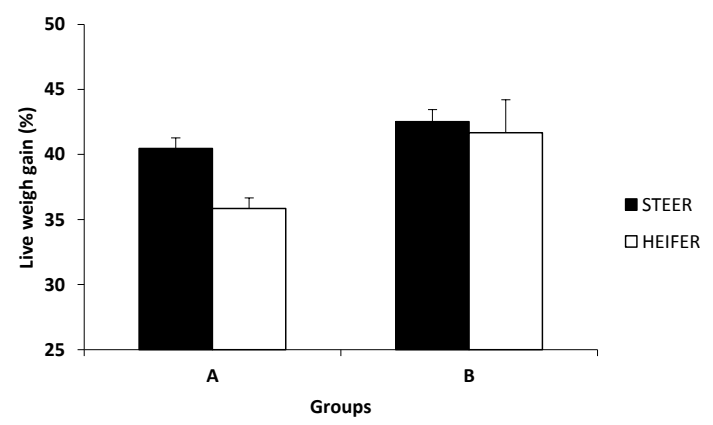

Figure 2 The liveweight gain (percentage of entry liveweight) of steers and heifers fed ad libitum fodder beet with $1 \mathrm{~kg}$ dry matter of additional forage for 130 days (means \pm SEM). Group A were 290-370 kg liveweight, group B were $240-260$ kg.

for slaughter ages of 14-18 months for finished primebeef carcasses.

Using data from all animals there was a weak, although statistically significant, positive relationship between entry liveweight and mean LWT gain/day $\left(\mathrm{R}^{2}=\right.$ 0.145; $\mathrm{P}<0.001)$ and even weaker negative relationship between entry liveweight and mean LWT gain \% $\left(\mathrm{R}^{2}\right.$ $=0.052 ; \mathrm{P}=0.001)$. These results indicate that only a small proportion of the variation in liveweight gain was accounted for by entry weight, and thus other factors, such as genetic potential and nutrition prior to fodder beet exposure, are influencing the performance of individual animals. There is no information available at present, but anecdotal industry reports have suggested both as factors to consider in selecting cattle for the system.

There were three deaths from the 392 animals fed fodder beet over the period, all the result of clostridial disease, and two temporary illnesses of undetermined cause. No clinical rumen acidosis cases were observed by attending veterinarians or by staff, and there were no observed cases of cattle refusing beet and requiring removal. The consistent intakes, strong mean LWT gains and range also do not suggest sub-clinical acidosis was a feature of the herd, as reduced intakes and subsequent post-slaughter incidence of hepatic abscessation (data not shown) are typical features of affected herds. These animal performance data suggest both satisfactory protein nutrition and rumen function in all groups, and a recent study (Prendergast \& Gibbs 2015) using cohort, co-grazing steers from this trial supports these conclusions.

The DM yield of the fodder beet crop transition face in autumn was estimated at $14-16 \mathrm{t} \mathrm{DM} /$ ha and the last hectare in spring at 26-28 t DM/ha. Given the fodder beet area was $20 \mathrm{ha}$, and that there was variation in the crop from the transition face area to the distant end of the area, the difference between autumn and spring 
was likely not to be primarily the result of autumn and winter crop growth.

The mean monthly rainfall for April, May and June was $83 \mathrm{~mm}$, higher than the historic mean of $53 \mathrm{~mm}$, and that for July, August and September was $22 \mathrm{~mm}$ against the historic mean of $45 \mathrm{~mm}$. The April rainfall was $161 \mathrm{~mm}$, and this resulted in local flooding on the farm and subsequently very wet soils throughout the next two months. This was likely to have impacted adversely on stock only in this period, with intakes potentially lower due to the difficulty of grazing the crop face in such soils.

\section{Summary and Conclusions}

In this trial the system of ad libitum fodder beet grazing with $1 \mathrm{~kg}$ DM daily silage supplement inputs across autumn and winter resulted in mean LWT gains of approximately $1 \mathrm{~kg}$ daily for steers with entry LWT above $290 \mathrm{~kg}$, and above $0.8 \mathrm{~kg}$ daily for heifers above $290 \mathrm{~kg}$ and both steers and heifers from $240-260 \mathrm{~kg}$ at entry. These LWT gains are higher than those previously reported for forage alternatives across this period. Industry experience and previous modelling suggests gains of this magnitude can be used to finish cattle for prime beef at conventional slaughter LWT liveweights ( $>500 \mathrm{~kg}$ steers; $>450 \mathrm{~kg}$ heifers) at $14-18$ months old, which is a significant advance in productivity for the beef industry.

While heavier steers were demonstrated to have a clear advantage in LWT gains compared to both lighter steers and heifers, both steers and heifers of all LWT in this trial were observed to have LWT gains suitable for effective use in this feeding system. Weaning LWT selection for this feeding system is currently conducted without any reference data for expected LWT gain differences due to entry weights. This research has provided necessary data to construct guidelines for these selections, and demonstrates producers could use $240 \mathrm{~kg}$ liveweight as a lower threshold without reducing performance beneath that required for finishing steers or heifers at less than 18 months old. Further research is required to determine the factors influencing markedly different LWT gain between individual animals in this system.

\section{REFERENCES}

Clark, D.A.; Woodward, S.I. 2007. Supplementation of dairy cows, beef cattle and sheep grazing pasture. In: Pasture and supplements for grazing animals. Eds. Rattray, P.V.; Brookes, I.M.; Nicol, A.M. Occasional Publication No. 14. New Zealand Society of Animal Production.

Gibbs, S.J. 2011. Fodder beet for wintering cows. In: Proceedings of the South Island Dairy Event Annual Conference. Lincoln University Press.
Gibbs, S.J.; Hughes, T.P. 2008. Support land for the dairy industry - the supply of supplements. pp. 115120. In: Proceedings of Annual Conference of the New Zealand Sheep and Beef Veterinary Association. Gibbs, S.J.; Saldias, B. 2014a. Fodder beet in the New Zealand dairy industry. In: Proceedings of the South Island Dairy Event Annual Conference. Lincoln University Press.

Gibbs, S.J.; Saldias, B. 2014b. Feeding fodder beet in New Zealand beef and sheep production. pp 8390. In: Proceedings of the Society of Sheep and Beef Veterinary Association of the New Zealand Veterinary Association.

Journeaux, P.R.; McRae, A.F.; Parker, W.J. 1987. Bull beef production on hill country. Proceedings of the New Zealand Society of Animal Production 47: 119122.

Joyce, J P.; Brunswick, L.C.F. 1977. Beef production from lucerne. Proceedings of the New Zealand Society of Animal Production 37: 67-71.

Korte, C.J.; Chu, A.C.P.; Field, T.R.O. 1987. Pasture Production. In: Livestock Feeding on Pasture. Ed. Nicol A.M. Occasional Publication No. 10. New Zealand Society of Animal Production.

McPherson, W.B.; Cairns, G.C.; Leaning, W.H.D.; Newcomb, K.M. 1989. Effect of different ivermectin treatments on weight gains in beef weaners. New Zealand Society of Animal Production: 49: 307-311.

Morris, S.T. 2013. The New Zealand beef cattle industry. Proceedings of the New Zealand Society of Animal Production 73: 1-4.

Prendergast, S.L.; Gibbs, S.J. 2015. A comparison of micobial protein synthesis in beef fed ad libitum winter ryegrass or fodder beet. Proceedings of the New Zealand Society of Animal Production 75: 251256.

Scales, G H., Taylor, A G. 1978. Compensatory growth of beef cattle. Proceedings of the New Zealand of Animal Production 38: 141-145.

Sheath, G.W, McCall D.G. 1994. Beef finishing systems. pp. 119-131 In: Proceedings of the Society of Sheep and Beef Cattle Veterinarians of the New Zealand Veterinary Association, Annual Conference. Thompson, K.F.; Monteath, M.A. 1974. Feed intake and growth in New Zealand feedlots. Proceedings of the New Zealand Society of Animal Production 34: 206-214.

Woods, P.W.; Couchman, J.N.; Barlow, H.A. 1995. Adapting cattle from pasture to brassica diets. Proceedings of the New Zealand Society of Animal Production 55: 251-254. 
